\title{
GC and GC/MS Analysis of Essential Oil Composition of the Endemic Soqotraen Leucas virgata Balf.f. and Its Antimicrobial and Antioxidant Activities
}

\author{
Ramzi A. Mothana ${ }^{1,2, *}$, Mansour S. Al-Said ${ }^{1}$, Mohammed A. Al-Yahya ${ }^{1}$, Adnan J. Al-Rehaily ${ }^{1}$ \\ and Jamal M. Khaled ${ }^{3}$
}

1 Department of Pharmacognosy, College of Pharmacy, King Saud University, P.O. Box 2457, Riyadh 11451, Saudi Arabia; E-Mails: msalsaid@ksu.edu.sa (M.S.A.); alyahya@ksu.edu.sa (M.A.A.); ajalreha@ksu.edu.sa (A.J.A.)

2 Department of Pharmacognosy, Faculty of Pharmacy, Sana'a-University, P.O. Box 33039, Sana'a, Yemen 3 Department of Botany and Microbiology, College of Science, King Saud University, Riyadh 11451, Saudi Arabia; E-Mail: jkhaled@ksu.edu.sa

* Author to whom correspondence should be addressed; E-Mail: rmothana@ksu.edu.sa or r_mothana@yahoo.com; Tel.: +966-11-4677256; Fax:+966-11-4677245.

Received: 24 October 2013; in revised form: 11 November 2013 / Accepted: 12 November 2013 / Published: 21 November 2013

\begin{abstract}
Leucas virgata Balf.f. (Lamiaceae) was collected from the Island Soqotra (Yemen) and its essential oil was obtained by hydrodistillation. The chemical composition of the oil was investigated by GC and GC-MS. Moreover, the essential oil was evaluated for its antimicrobial activity against two Gram-positive bacteria, two Gram-negative bacteria, and one yeast species by using broth micro-dilution assay for minimum inhibitory concentrations (MIC) and antioxidant activity by measuring the scavenging activity of the DPPH radical. The investigation led to the identification of 43 constituents, representing $93.9 \%$ of the total oil. The essential oil of $L$. virgata was characterized by a high content of oxygenated monoterpenes (50.8\%). Camphor (20.5\%) exo-fenchol (3.4\%), fenchon (5.4\%), and borneol (3.1\%) were identified as the main components. Oxygenated sesquiterpenes were found as the second major group of compounds $(21.0 \%)$. $\beta$-Eudesmol $(6.1 \%)$ and caryophyllene oxide $(5.1 \%)$ were the major compounds among oxygenated sesquiterpenes. The results of the antimicrobial assay showed that the oil exhibited a great antibacterial activity against the tested S. aureus, B. subtilis, and E. coli. No activity was found against $P$. aeruginosa and C. albicans. Moreover, the DPPH-radical scavenging assay exhibited only a moderate antioxidant activity (31\%) for the oil at the highest concentration tested $(1 \mathrm{mg} / \mathrm{mL})$.
\end{abstract}


Keywords: Leucas virgata; Soqotra; essential oil; antimicrobial; antioxidant

\section{Introduction}

Aromatic plants are frequently used in traditional medicine because of their essential oils and volatile constituents. In last few years, there has been an increase in the use of aromatic medicinal plants and their essential oils in scientific research and industrial applications including nutritional, pharmaceutical, and cosmetic uses [1-4]. At present, approximately 3000 essential oils are known, 300 of which are commercially important especially for the pharmaceutical, agronomic, food, cosmetic, and perfume industry [5]. Moreover, various potent biological activities including antimicrobial, antioxidant, anti-inflammatory, and anticancer are attributed to essential oils [6-11]. As essential oils represent a source of antimicrobial, antioxidants and anticancer components, they are currently attracting increasing interest in the scientific community and there is much research being performed on their pharmacological activities, particularly their antimicrobial, antioxidant, anti-inflammatory, and anticancer properties, which are important in the prevention and treatment of diseases of microbial and oxidative stress origin, such as bacterial and viral infections, inflammations, cancers, and cardiovascular diseases, including atherosclerosis and thrombosis [12-19].

The Soqotra Archipelago in Yemen has long been considered the "jewel" of biodiversity in the Arabian Sea. The long geological isolation of the Soqotra archipelago has created a unique and spectacular endemic flora. Surveys have revealed that more than a third of the 800 or so plant species of Soqotra are found nowhere else [20].

The genus Leucas (family: Lamiaceae) comprises about eighty species. The highest species diversity has been found in East Africa [21]. The genus Leucas is represented in Soqotra Island by ten species including the endemic Leucas virgata Balf.f., which occur as widespread and abundant much-branched aromatic shrub, up to $1 \mathrm{~m}$ in height [20]. The sprigs and leaves are used as a tea or powder for heartburn and indigestion, as well as to treat a variety of stomach problems [20].

As a part of our phytochemical and biological studies on natural essential oils and their possible antimicrobial and antioxidant activities, the aim of this work was to investigate the chemical composition of the essential oil of one of the endemic traditionally used Lamiaceae species namely, Leucas virgata. Moreover, in this study we examined the antimicrobial and the radical scavenging activities of this essential oil.

\section{Results and Discussion}

\subsection{Chemical Composition of the L. virgata Essential Oil}

The essential oil of the aerial part of L. virgata obtained after hydrodistillation was colorless and possessed an aromatic odor. It gave an average yield of $0.28 \%$ on dry weight basis. The chemical composition of the oil is presented in Table 1, in which the compounds are listed in order of their elution on the CP-Sil 5 CB column. The chemical components were grouped in different classes of compounds. A total of 43 constituents, representing $93.9 \%$ of the total oil, were identified by gas 
chromatographic and mass spectrometric data. It is important to mention that there have been no reports on GC-MS analysis of the essential oil of this endemic Leucas species. Additionally, this study represents the first report on the antimicrobial and antioxidant activities of the essential oil. L. virgata essential oil was characterized by high content of oxygenated monoterpenes $(50.8 \%)$. Among them, camphor (20.5\%), fenchon (5.4\%), exo-fenchol (3.4\%), and borneol (3.1\%) were identified as the main components (Table 1). Oxygenated sesquiterpenes were found as the second major group of compounds (21.0\%), of which $\beta$-eudesmol (6.1\%) and caryophyllene oxide $(5.1 \%)$ were the major compounds (Table 1). Furthermore, monoterpene hydrocarbons and sesquiterpene hydrocarbons amounted only to $8.1 \%$ and $13.8 \%$ respectively (Table 1 ). Based on the data published so far, our results appeared to be somewhat different from previously reported data on the chemical composition of other Leucas essential oils.

In previous studies [22-26], the chemical composition of the essential oils of different Leucas species e.g., L. glabrata, L. aspera, L. milanjiana, L. deflexa, and L. cephalotes was investigated. The results obtained by Vagionas et al. [22] for the essential oil of L. glabrata, revealed that the most abundant chemical category was the oxygenated monoterpenes $(64.4 \%)$ as well, however, other compounds e.g., menthone (31.8\%), pulegone $(11.4 \%)$, piperitone $(10.6 \%)$, and piperitenone $(6.7 \%)$ were the major volatiles. Moreover, the GC-MS analysis of the volatile oil of L. aspera identified carvone, carvacrol, menthol, phellandral, and farnesene as major components [23], whereas high content of $\beta$-cubebene, $\alpha$-pinene, trans-caryophyllene, and limonene was reported for the essential oil of L. milanjiana [24]. These results suggest that phenological stage of the plant as well as geographical environmental factors almost certainly contributed to create a spectacular chemical composition of $L$. virgata.

Table 1. Chemical composition of the essential oil Leucas virgata.

\begin{tabular}{ccccc}
\hline No. & Compounds & RI & \% Occurrence & Identification \\
\hline 1 & $\alpha$-Pinene & 932 & 1.7 & 1,2 \\
2 & Camphene & 948 & 1.8 & 1,2 \\
3 & Sabinene & 967 & 0.1 & $1,2,3$ \\
4 & $\beta$-Pinene & 975 & 2.3 & $1,2,3$ \\
5 & 2-Pentylfuran & 982 & 0.3 & $1,2,3$ \\
6 & $\alpha$-Phellandrene & 998 & 0.3 & $1,2,3$ \\
7 & $p$-Cymene & 1014 & 0.5 & 1,2 \\
8 & Limonene & 1024 & 1.0 & $1,2,3$ \\
9 & $\gamma$-Terpinene & 1051 & 0.2 & $1,2,3$ \\
10 & $t$-Linalool oxide & 1059 & 1.2 & 1,2 \\
11 & Fenchone & 1070 & 5.4 & 1,2 \\
12 & Linalool & 1085 & 2.7 & $1,2,3$ \\
13 & $\alpha$-Fenchol & 1102 & 2.0 & $1,2,3$ \\
14 & Exo-Fenchol & 1111 & 3.4 & 1,2 \\
15 & Camphor & 1125 & 20.5 & 1,2 \\
16 & Pinocarvone & 1142 & 2.1 & 1,2 \\
17 & Borneol & 1152 & 3.1 & $1,2,3$ \\
18 & Terpinen-4-ol & 1165 & 2.0 & $1,2,3$ \\
19 & $\alpha$-Terpineol & 1176 & 3.0 & 1,2 \\
\hline
\end{tabular}


Table 1. Cont.

\begin{tabular}{|c|c|c|c|c|}
\hline No. & Compounds & RI & $\%$ Occurrence & Identification \\
\hline 20 & Myrtenol & 1182 & 2.9 & $1,2,3$ \\
\hline 21 & trans-Carveol & 1201 & 0.9 & 1,2 \\
\hline 22 & cis-Carveol & 1213 & 0.2 & 1,2 \\
\hline 23 & Carvone & 1219 & 0.6 & 1,2 \\
\hline 24 & $t$-Geraniol & 1236 & 0.1 & 1,2 \\
\hline 25 & Bornyl acetate & 1272 & 0.2 & 1,2 \\
\hline 26 & Carvacrol & 1281 & 0.4 & $1,2,3$ \\
\hline 27 & Eugenol & 1333 & 0.1 & 1,2 \\
\hline 28 & (E)- $\beta$-Caryophyllene & 1423 & 0.7 & $1,2,3$ \\
\hline 29 & trans-Bergamotene & 1434 & 0.4 & 1,2 \\
\hline 30 & $\alpha$-Humulene & 1456 & 1.6 & 1,2 \\
\hline 31 & $\beta$-Ionene & 1463 & 0.6 & 1,2 \\
\hline 32 & $\gamma$-Muurolene & 1475 & 2.9 & 1,2 \\
\hline 33 & $\beta$-Selinene & 1488 & 2.4 & 1,2 \\
\hline 34 & $\beta$-Curcumene & 1502 & 1.8 & 1,2 \\
\hline 35 & $\alpha$-Alaskene & 1513 & 1.7 & 1,2 \\
\hline 36 & $\alpha$-Calacorene & 1535 & 1.7 & 1,2 \\
\hline 37 & Caryophyllene oxide & 1580 & 5.1 & 1,2 \\
\hline 38 & Humulene epoxide II & 1604 & 3.1 & 1,2 \\
\hline 39 & $\gamma$-Eudesmol & 1623 & 3.4 & 1,2 \\
\hline 40 & $\beta$-Eudesmol & 1646 & 6.1 & 1,2 \\
\hline 41 & $\begin{array}{l}\text { Isoaromadendrene } \\
\text { epoxide }\end{array}$ & 1663 & 0.4 & 1,2 \\
\hline 42 & $\beta$-Bisabolol & 1674 & 2.9 & 1,2 \\
\hline 43 & $\begin{array}{l}n \text {-Tetradecanoic acid } \\
\text { Monoterpene } \\
\text { hydrocarbons }\end{array}$ & 1745 & $\begin{array}{l}0.2 \\
8.1\end{array}$ & $\begin{array}{l}1,2 \\
-\end{array}$ \\
\hline & Oxygenated monoterpenes & & 50.8 & - \\
\hline & $\begin{array}{l}\text { Sesquiterpene } \\
\text { hydrocarbons }\end{array}$ & & 13.8 & - \\
\hline & $\begin{array}{c}\text { Oxygenated } \\
\text { sesquiterpenes }\end{array}$ & & 21.0 & - \\
\hline & Aliphatic acids & & 0.2 & - \\
\hline & Total & & 93.9 & - \\
\hline
\end{tabular}

Notes: RI, retention indices relative to $\mathrm{C} 8-\mathrm{C} 30$ n-alkanes on the CP-Sil 5 CB column, tr: traces, 1: retention index, 2: mass spectrum, 3: co-injection with authentic compound.

\subsection{Antimicrobial Activity}

To analyze the antimicrobial activity of the essential oil, the broth microdilution method was employed to determine the minimum inhibitory concentration (MIC) against selected microorganisms. The results of the antimicrobial activity are shown in Table 2. The results exhibited that the essential oil had varying degrees of growth inhibition against the bacterial strains (Table 2). In general, the tested Gram-positive bacterial strains showed more susceptibility to the investigated essential oil than 
the Gram-negative bacterial strains. The essential oil of L. virgata showed a strong antimicrobial activity against $B$. subtilis, S. aureus, and E. coli with MIC values of $0.28,0.56$, and $4.5 \mathrm{mg} / \mathrm{mL}$, respectively (Table 2). However, no obvious inhibitory activity was observed against $P$. aeruginosa and $C$. albicans. Obviously, our result is in agreement with data reported on the antimicrobial effect of essential oils as well as methanolic extracts from other Leucas species [22,23,27,28]. Vagionas et al. [22] reported that the tested essential oil of L. glabrata has a strong antimicrobial activity against two Gram-positive and four Gram-negative bacteria, three pathogenic fungi, and two oral pathogens (MIC values $0.45-1.14 \mathrm{mg} / \mathrm{mL}$ ). It was reported that the antimicrobial activity could be attributed to the high content of the oil in compounds with known antimicrobial activity, such as menthone [29], pulegone, and piperitone [30]. Moreover, Satyal et al. [31] recently reported that the essential oil of L. aspera exhibited no activity against E. coli, $P$. aeruginosa, and C. albicans (MIC $>1250 \mu \mathrm{g} / \mathrm{mL}$ ) but good activity against $S$. aureus $(625 \mu \mathrm{g} / \mathrm{mL})$ and $B$. cereus $(313 \mu \mathrm{g} / \mathrm{mL})$. A similar study was conducted by Gerige et al. [23] who reported similar results for L. aspera. Schmidt et al. [32] and Satyal et al. [31] attributed this effect to the high percentage of sesquiterpenes such as $(E)$-caryophyllene and $\alpha$-humulene, which have shown antibacterial activity against $S$. aureus and $B$. cereus. In addition to that, oxygenated monoterpenes, such as camphor, borneol, linalool, and $\alpha$-terpineol, were reported to be responsible for the antimicrobial activity of several essential oils [33-35]. Consequently, the observed strong antibacterial effect of L. virgata might be attributed to the high percentage of oxygenated monoterpenes, such as camphor, $\alpha$-fenchol, fenchon, borneol, and $\alpha$-terpineol. Possible synergistic effect of some compounds in the oils e.g., oxygenated sesquiterpenes (caryophyllene oxide, humulene oxide II, $\beta$-eudesmol, $\gamma$-eudesmol, and $\beta$-bisabolol) should also be taken in consideration.

Table 2. Antimicrobial activity (minimum inhibitory concentration (MIC)-values) and free radical scavenging activity of the investigated essential oil of L. virgata.

\begin{tabular}{|c|c|c|c|c|c|c|c|c|c|c|}
\hline \multirow{2}{*}{$\begin{array}{c}\text { Plant } \\
\text { species }\end{array}$} & \multicolumn{5}{|c|}{ Radical scavenging activity in \% } & \multicolumn{5}{|c|}{$\mathrm{MIC}^{\mathrm{a}}$} \\
\hline & $\begin{array}{c}10 \\
(\mu \mathrm{g} / \mathrm{mL})\end{array}$ & $\begin{array}{c}50 \\
(\mu \mathrm{g} / \mathrm{mL})\end{array}$ & $\begin{array}{c}100 \\
(\mu \mathrm{g} / \mathrm{mL})\end{array}$ & $\begin{array}{c}500 \\
(\mu \mathrm{g} / \mathrm{mL})\end{array}$ & $\begin{array}{c}1000 \\
(\mu \mathrm{g} / \mathrm{mL})\end{array}$ & $\begin{array}{c}S . \\
\text { aureus } \\
\end{array}$ & $\begin{array}{c}B . \\
\text { subtilis }\end{array}$ & $\begin{array}{c}E . \\
\text { coli }\end{array}$ & $\begin{array}{c}P . \\
\text { aeruginosa }\end{array}$ & $\begin{array}{c}C . \\
\text { albicans }\end{array}$ \\
\hline L.virigata & 5.9 & 6.1 & 10.4 & 18.4 & 31.0 & 0.56 & 0.28 & 4.48 & - & - \\
\hline Amoxicillin & - & - & - & - & - & 3.5 & 3.5 & nt & $\mathrm{nt}$ & $\mathrm{nt}$ \\
\hline Gentamicin & - & - & - & - & - & $\mathrm{nt}$ & $\mathrm{nt}$ & 3.5 & 7.0 & $\mathrm{nt}$ \\
\hline Nystatin & - & - & - & - & - & $\mathrm{nt}$ & $\mathrm{nt}$ & nt & $\mathrm{nt}$ & 3.5 \\
\hline Ascorbic acid & 43.5 & 84.3 & 92.6 & 96.5 & 95.2 & - & - & - & - & - \\
\hline
\end{tabular}

Notes: a: minimum inhibitory concentration values are given as $\mathrm{mg} / \mathrm{mL}$ for essential oils and $\mu \mathrm{g} / \mathrm{mL}$ for standard antibiotics, nt: not tested.

\subsection{Antioxidant Activity}

The potential antioxidant activity of the essential oil was determined on the basis of scavenging activity of the free radical DPPH. The investigated essential oil of L. virgata demonstrated only moderate antioxidant abilities to reduce DPPH (Table 2) at the highest concentration tested (31\% at $1 \mathrm{mg} / \mathrm{mL}$ ). This observed effect could be associated with low content of volatile phenolic components, such as thymol and carvacrol in the oil [36]. This result seems to be in agreement with results reported by Vagionas et al. [22] who demonstrated that the tested essential oil of L. glabrata has a 
weak antioxidant activity. It is interesting to point out that we previously investigated the antioxidant activity of the methanolic extract of L. virgata [37]. The methanolic extract showed high radical scavenging activity $(80 \%)$ at $1 \mathrm{mg} / \mathrm{mL}$. In agreement with that result, remarkable antioxidant activity was reported for the methanolic and ethanolic extracts of other Leucas species, such as L. mollissima and L. aspera [38,39]. Recently, similar results were published for extracts of L. aspera, L. martinicensis, and L. lanata [40-42]. It was shown that these extracts had strong antiradical scavenging activity [38-42]. It was found that the interesting antioxidant effect is attributed to the presence of flavonoids and other phenolic compounds $[42,43]$. Thus, the notable antioxidant activity of the methanolic extract of L. virgata should be attributed to the phenolic and flavonoidal content [37].

\section{Experimental Section}

\subsection{Plant Material}

The aerial part (including flowers, leaves, and stems) of the plant was collected from the island Soqotra in February 2007, and identified at the Pharmacognosy Department, Faculty of Pharmacy, Sana'a University. Voucher specimens were deposited at the Pharmacognosy Department, Faculty of Pharmacy, Sana'a University.

\subsection{Isolation of the Essential Oil}

The air-dried and ground aerial part of L. virgata was submitted for hydrodistillation $(3 \mathrm{~h})$ in a Clevenger-type apparatus according to the European Pharmacopoeia. As a collector solvent, $1.5 \mathrm{~mL}$ of $n$-heptane was used. The obtained essential oil was dried over anhydrous sodium sulphate and after filtration and evaporation under nitrogen-flow, stored in sealed vials at $+4{ }^{\circ} \mathrm{C}$ until tested and analyzed.

\subsection{Gas Chromatography Analysis}

The volatile oil was analyzed using a Hewlett Packard 5890 series II GC equipped with a Flame Ionization Detector (FID). The analysis was carried out on a fused silica capillary CP-Sil 5 CB column (Agilent Technologies, Santa Clara, CA, USA) $(30 \mathrm{~m} \times 0.25 \mathrm{~mm}$ i.d., film thickness $0.25 \mu \mathrm{m})$. Nitrogen was used as a carrier gas at a flow rate of $0.46 \mathrm{~mL} / \mathrm{min}$. Injector and detector temperature were set at $200{ }^{\circ} \mathrm{C}$ and $280{ }^{\circ} \mathrm{C}$, respectively. Oven temperature was kept at $45{ }^{\circ} \mathrm{C}$ then gradually raised to $280{ }^{\circ} \mathrm{C}$ at $3{ }^{\circ} \mathrm{C} / \mathrm{min}$ and finally held isothermally for $22 \mathrm{~min}$. One microliter of the diluted samples $(1 / 100$ in heptane, $v / v)$ were injected manually (split mode, split ratio 1:16). Calculation of peak area percentage was performed on basis of the FID signal using the GC HP-Chemstation software (Agilent Technologies, Santa Clara, CA, USA).

\subsection{Gas Chromatography-Mass Spectrometry}

The GC-MS analysis of the oil was performed on a Hewlett-Packard 5890 gas chromatograph, coupled to VG Analytical 70-250S mass spectrometer. The GC was equipped with a fused silica capillary CP-Sil $5 \mathrm{CB}$ column $(25 \mathrm{~m} \times 0.25 \mathrm{~mm}$ i.d., film thickness $0.40 \mu \mathrm{m}$, from Chromback, Varian). Helium was used as carrier gas at flow rate of $1 \mathrm{~mL} / \mathrm{min}$. The oven program started with an 
initial temperature of $80{ }^{\circ} \mathrm{C}$ held for $2 \mathrm{~min}$ and then the oven temperature was heated at $10{ }^{\circ} \mathrm{C} / \mathrm{min}$ to $270{ }^{\circ} \mathrm{C}$ and finally held isothermally for $20 \mathrm{~min}$. For GC-MS detection, an election ionization system, with ionization energy of $70 \mathrm{eV}$ was used. A scan rate of $0.6 \mathrm{~s}$ (cycle time: $0.2 \mathrm{~s}$ ) was applied, covering a mass range from 35 to $600 \mathrm{amu}$.

\subsection{Identification of Components}

The identification of the compounds was based on the comparison of retention indices and mass spectra of most of the compounds with data generated under identical experimental conditions by applying a two-dimensional search algorithm, considering the retention index, as well as mass spectral similarity [44,45], or with those of authentic compounds available in our laboratories. Moreover, special software, namely MassLib software (V9.3-106; 1996-2008, Max-Planck-Institute for Kohlenforschung, Muelheim, Germany) was used for processing and interpretation of mass spectra with several commercially available libraries included: Wiley Registry of Mass Spectral Data (4th Ed.), NIST/EPA/NIH Mass Spectral Library (2005), Library MPI Mühlheim (2006), Geochemicals (1st Ed.), MRC collection (1st Ed.), and CC (4th Ed.) [45]. The retention indices (RI) were in relation to a homologous series of $n$-alkanes $\left(\mathrm{C}_{6}-\mathrm{C}_{28}\right)$ on the CP-Sil $5 \mathrm{CB}$ column under the same chromatographic conditions. Components relative concentrations were obtained by peak area normalization. No response factors were calculated.

\subsection{Determination of Antimicrobial Activity}

\subsubsection{Test Organisms}

The following microorganisms were used as test organisms in the screening: Staphylococcus aureus (BNI 18), Bacillus subtilis (BNI 28), Escherichia coli (BNI 2), Pseudomonas aeruginosa (BNI 20), and Candida albicans (BNI 33). The microbial strains were obtained from the Bernhard-Nocht-Institute (BNI) for Tropical Medicine, Hamburg, Germany.

\subsubsection{Broth Micro-Dilution Assay for Minimum Inhibitory Concentrations (MIC)}

The antimicrobial activity of the essential oil was determined by the broth micro-dilution method described by Mann and Markham [46] with modifications against the above-mentioned microbial strains. With sterile round-bottom 96-well plates, duplicate two-fold serial dilutions of extract (100 $\mu \mathrm{L} /$ well) were prepared in the appropriate broth containing 5\% $(v / v)$ DMSO. Two-fold dilutions of amoxicillin, gentamicin, or nystatin were used as a positive control. A bacterial cell suspension (prepared in the appropriate broth) of $100 \mu \mathrm{L}$, corresponding to $1 \times 10^{6} \mathrm{CFU} / \mathrm{mL}$, was added in all wells except those in columns 10,11, and 12, which served as saline, essential oil, and media sterility controls, respectively. Controls for bacterial growth without essential oil were also included on each plate. The final concentration of bacteria in the assay was $5 \times 10^{5} \mathrm{CFU} / \mathrm{mL}$. Plates were then incubated at $37^{\circ} \mathrm{C}$ for $18 \mathrm{~h}$ overnight. After incubation, the MIC of each essential oil was determined as the lowest concentration at which no growth was observed in the duplicate wells. Twenty microliters of a $p$-iodonitro-tetrazolium violet solution $(0.04 \%, w / v)$ (Sigma, St. Louis, MO, USA) was then added to each well. The plates were incubated for a further $30 \mathrm{~min}$, and estimated visually for any change in color from yellow to 
pink, indicating reduction of the dye due to bacterial growth. The highest dilution (lowest concentration) that remained yellow corresponded to the MIC. Experiments were performed in duplicate.

\subsection{Determination of Antioxidant Activity (Scavenging Activity of DPPH Radical)}

The DPPH free radical scavenging assay was carried out for the evaluation of the antioxidant activity. This assay measures the free radical scavenging capacity of the investigated essential oil. DPPH is a molecule containing a stable free radical. In the presence of an antioxidant which can donate an electron to DPPH, the purple color, typical for free DPPH radical decays, and the change in absorbency at $\lambda=517 \mathrm{~nm}$ is followed spectrophotometrically. This test provides information on the ability of a compound to donate a hydrogen atom, on the number of electrons a given molecule can donate, and on the mechanism of antioxidant action. The method was carried out as described previously [47]. The essential oil was dissolved in methanol, and various concentrations (10, 50, 100, 500 , and $1000 \mu \mathrm{g} / \mathrm{mL}$ ) were used. The assay mixture contained in a total volume of $1 \mathrm{~mL}, 500 \mu \mathrm{L}$ of the oil, $125 \mu \mathrm{L}$ prepared DPPH (1 mM in methanol), and $375 \mu \mathrm{L}$ solvent (methanol). After 30 min incubation at $25{ }^{\circ} \mathrm{C}$, the decrease in absorbance was measured at $\lambda=517 \mathrm{~nm}$. The radical scavenging activity was calculated from the equation:

$\%$ of radical scavenging activity $=$ Abscontrol - Abssample $/$ Abscontrol $\times 100$

\section{Conclusions}

In conclusion our study is the first report on the chemical composition and in vitro antimicrobial and antioxidant activities of the essential oil of the Soqotraen Leucas virgata. The GC and GC/MS analysis of the essential oil revealed that the chemical composition was characterized by high content of oxygenated monoterpenes (50.8\%). Camphor, exo-fenchol, fenchon, and borneol were identified as the main components. It was shown that the chemical compositions differed from that of other well-investigated Leucas species. Moreover, the results clearly showed that the essential oil of L. virgata possesses potent antimicrobial but moderate antioxidant activity. Our results further support the idea that $L$ virgata can be promising source of potential antimicrobial agents.

\section{Acknowledgments}

The authors extend their appreciation to the Deanship of Scientific Research at King Saud University for funding the work through the research group project No. (RGP-VPP-073).

\section{Conflicts of Interest}

The authors declare no conflict of interests.

\section{References}

1. Zuzarte, M.; Gonçalves, M.J.; Cavaleiro, C.; Dinis, A.M.; Canhoto, J.M.; Salgueiro, L.R. Chemical composition and antifungal activity of the essential oils of Lavandula pedunculata (Miller) Cav. Chem. Biodivers. 2009, 8, 1283-1292. 
2. Cheng, S.S.; Lin, H.Y.; Chang, S.T. Chemical composition and antifungal activity of essential oils from different tissues of Japanese cedar (Cryptomeria japonica). J. Agric. Food Chem. 2005, 53, 614-619.

3. Ksouri, R.; Falleh, H.; Megdiche, W.; Trabelsi, N.; Mhamdi, B.; Chaieb, K.; Bakrouf, A.; Magné, C.; Abdelly, C. Antioxidant and antimicrobial activities of the edible medicinal halophyte Tamarix gallica L. and related polyphenolic constituents. Food Chem. Toxicol. 2009, 47, 2083-2091.

4. Tsai, M.L.; Lin, C.C.; Lin, W.C.; Yang, C.H. Antimicrobial, antioxidant, and anti-inflammatory activities of essential oils from five selected herbs. Biosci. Biotechnol. Biochem. 2011, 75, 1977-1983.

5. Bakkali, F.; Averbeck, S.; Averbeck, D.; Idaomar, M. Biological effects of essential oils-A review. Food Chem. Toxicol. 2008, 46, 446-475.

6. Edris, A.E. Pharmaceutical and therapeutic potentials of essential oils and their individual volatile constituents: A review. Phytother. Res. 2007, 21, 308-323.

7. Burt, S. Essential oils: Their antibacterial properties and potential applications in foods-A review. Int. J. Food Microbiol. 2004, 94, 223-253.

8. Chao, L.K.; Hua, K.F.; Hsu, H.Y.; Cheng, S.S.; Liu, J.Y.; Chang, S.T. Study on the antiinflammatory activity of essential oil from leaves of Cinnamomum osmophloeum. J. Agric. Food Chem. 2005, 53, 7274-7278.

9. Su, Y.C.; Hsu, K.P.; Wang, E.I.; Ho, C.L. Composition and in vitro anticancer activities of the leaf essential oil of Neolitsea variabillima from Taiwan. Nat. Prod. Commun. 2013, 8, 531-532.

10. Misra, L.N.; Wouatsa, N.A.V.; Kumar, S.; Kumar, R.V.; Tchoumbougnang, F. Antibacterial, cytotoxic activities and chemical composition of fruits of two Cameroonian Zanthoxylum species. J. Ethnopharmacol. 2013, 148, 74-80.

11. Afoulous, S.; Ferhout, H.; Raoelison, E.G.; Valentin, A.; Moukarzel, B.; Couderc, F.; Bouajila, J. Chemical composition and anticancer, antiinflammatory, antioxidant and antimalarial activities of leaves essential oil of Cedrelopsis grevei. Food Chem. Toxicol. 2013, 56, 352-362.

12. Jallali, I.; Zaouali, Y.; Missaoui, I.; Smeoui, A.; Abdelly, C.; Ksouri, R. Variability of antioxidant and antibacterial effects of essential oils and acetonic extracts of two edible halophytes: Crithmum maritimum L. and Inula crithmoïdes L. Food Chem. 2014, 145, 1031-1038.

13. Lamia, C.; Laura, E.; Mohammed, B.; Diego, G.G.; Rafael, P.; Amin, L. Chemical composition and antioxidant properties of Laurus nobilis L. and Myrtus communis L. essential oils from Morocco and evaluation of their antimicrobial activity acting alone or in combined processes for food preservation. J. Sci. Food Agric. 2013, doi:10.1002/jsfa.6397.

14. Hamdan, D.; Ashour, M.L.; Mulyaningsih, S.; El-Shazly, A.; Wink, M. Chemical composition of the essential oils of variegated pink-fleshed lemon (Citrus $x$ limon L. Burm. f.) and their anti-inflammatory and antimicrobial activities. Z. Naturforsch. C. 2013, 68, 275-284.

15. Nakata, M.; Myoda, T.; Wakita, Y.; Sato, T.; Tanahashi, I.; Toeda, K.; Fujimori, T.; Nishizawa, M. Volatile components of essential oil from cultivated Myrica gale var. tomentosa and its antioxidant and antimicrobial activities. J. Oleo Sci. 2013, 62, 755-762. 
16. Senatore, F.; Oliviero, F.; Scandolera, E.; Taglialatela-Scafati, O.; Roscigno, G.; Zaccardelli, M.; de Falco, E. Chemical composition, antimicrobial and antioxidant activities of anethole-rich oil from leaves of selected varieties of fennel [Foeniculum vulgare Mill. ssp. vulgare var. azoricum (Mill.) Thell]. Fitoterapia 2013, 90, 214-219.

17. Mothana, R.A.A.; Hasson, S.S.; Schultze, W.; Mowitz, A.; Lindequist, U. Phytochemical composition and in vitro antimicrobial and antioxidant activities of essential oils of three endemic Soqotraen Boswellia species. Food Chem. 2011, 126, 1149-1154.

18. Salleh, W.M.N.H.W.; Ahmad, F.; Yen, K.H.; Sirat, H.M. Chemical Compositions, antioxidant and antimicrobial activities of essential oils of Piper caninum Blume. Int. J. Mol. Sci. 2011, 12, 7720-7731.

19. Mothana, R.A.; Al-Rehaily, A.J.; Schultze, W. Chemical analysis and biological activity of the essential oils of two endemic Soqotri Commiphora species. Molecules 2010, 15, 689-698.

20. Miller, A.G.; Morris, M. Ethnoflora of the Soqotra Archipelago; The Royal Botanic Garden Edinburgh, the Charlesworth Group: Huddersfield, UK, 2004.

21. Das, S.N.; Patro, V.J.; Dinda, S.C. A review: Ethnobotanical survey of genus Leucas. Pharmacogn. Rev. 2012, 6, 100-106.

22. Vagionas, K.; Ngassapa, O.; Runyoro, D.; Graikou, K.; Gortzi, O.; Chinou, I. Chemical analysis of edible aromatic plants growing in Tanzania. Food Chem. 2007, 105, 1711-1717.

23. Gerige, S.J.; Yadav, M.K.; Rao, D.M.; Ramanjeneyulu, R. GC-MS analysis and inhibitory efficacy of Leucas aspera L. leaf volatile oil against selected microbes. Niger. J. Nat. Prod. Med. 2007, 11, 80-83.

24. Mangathayaru, K.; Thirumurugan, D.; Patel, P.S.; Pratap, D.V.; David, D.J.; Karthikeyan, J. Isolation and identification of nicotine from Leucas aspera (willd) link. Indian J. Pharm. Sci. 2006, 68, 88-90.

25. Moody, J.O.; Gundidza, M.; Wyllie, G. Essential oil composition of Leucas milanjiana Guerke. Flavour Fragr. J. 2006, 21, 872-874.

26. Mve-Mba, C.E.; Menut, C.; Lamaty, G.; Zollo, P.H.; Thoumbougnang, F.; Bessiere, J. Aromatic plants of tropical central Africa. Part XIX. Volatile components from leaves of two Lamiaceae from Cameroon: Leucas deflexa hook and Solenostemon monostachyus (P. Beauv.) Briq. Flavour Fragr. J. 1994, 9, 315-317.

27. Mangathayaru, K.; Lakshmikant, J.; Sundar, N.S.; Swapna, R.; Grace, X.F.; Vasantha, J. Antimicrobial activity of Leucas aspera flowers. Fitoterapia 2005, 76, 752-754.

28. Rajakaruna, N.; Harris, C.S.; Towers, G.H.N. Antimicrobial activity of plants collected from serpentine outcrops in Sri Lanka. Pharm. Biol. 2002, 40, 235-244.

29. Duru, M.E.; Oztürk, M.; Uğur, A.; Ceylan, O. The constituents of essential oil and in vitro antimicrobial activity of Micromeria cilicica from Turkey. J. Ethnopharmacol. 2004, 94, 43-48.

30. Oumzil, H.; Ghoulami, S.; Rhajaoui, M.; Ilidrissi, A.; Fkih-Tetouani, S.; Faid, M.; Benjouad, A. Antibacterial and antifungal activity of essential oils of Mentha suaveolens. Phytother. Res. 2002, 16, 727-731.

31. Satyal, P.; Paudel, P.; Poudel, A.; Setzer, W.N. Microbiological activities of volatile constituents of Leucas aspera (willd.) Link from Nepal. J. Nat. Pharm. 2012, 3, 118-119. 
32. Schmidt, J.M.; Noletto, J.A.; Volger, B.; Setzer, W.N. Chemical composition of the essential oils of four aromatic medicinal plants from Abaco island, Bahamas. J. Herbs Spices Med. Plants. 2006, 12, 43-65.

33. Carson, C.F.; Riley, T.V. Antimicrobial activity of the major components of the essential oil of Melaleuca alternifolia. J. Appl. Bacteriol. 1995, 78, 264-269.

34. Pattnaik, S.; Subramanyam, V.R.; Bapaji, M.; Kole, C.R. Antibacterial and antifungal activity of aromatic constituents of essential oils. Microbios 1997, 89, 39-46.

35. Kim, K.J.; Kim, Y.H.; Yu, H.H.; Jeong, S.I.; Cha, J.D.; Kil, B.S.; You, Y.O. Antibacterial activity and chemical composition of essential oil of Chrysanthemum boreale. Planta Med. 2003, 69, 274-277.

36. Ruberto, G.; Baratta, M.T. Antioxidant activity of selected essential oil components in two lipid model systems. Food Chem. 2000, 69, 167-174.

37. Mothana, R.A.; Lindequist, U.; Gruenert, R.; Bednarski, P.J. Studies of the in vitro anticancer, antimicrobial and antioxidant potentials of selected Yemeni medicinal plants from the island Soqotra. BMC Complement. Altern. Med. 2009, 9, 7, doi:10.1186/1472-6882-9-7.

38. Shyur, L.F.; Tsung, J.H.; Chen, J.H.; Chiu, C.Y.; Lo, C.P. Antioxidant properties of extracts from medicinal plants popularly used in Taiwan. Int. J. Appl. Sci. Eng. 2005, 3, 195-202.

39. Rahman, M.S.; Sadhu, S.K.; Hasan, C.M. Preliminary antinociceptive, antioxidant and cytotoxic activities of Leucas aspera root. Fitoterapia 2007, 78, 552-555.

40. Rahman, M.A.; Islam, M.S. Antioxidant, antibacterial and cytotoxic effects of the phytochemicals of whole Leucas aspera extract. Asian Pac. J. Trop .Biomed. 2013, 3, 273-279.

41. Ramalingam, R.; Nath, A.R.; Madhavi, B.B.; Nagulu, M. In vitro free radical scavenging, cytotoxic and acetylcholinesterase inhibitory activities of Leucas martinicensis. Int. J. Chem. Anal. Sci. 2013, 4, 91-95.

42. Ramalingam, R.; Nath, A.R.; Madhavi, B.B.; Nagulu, M.; Balasubramaniam, A. Free radical scavenging and antiepileptic activity of Leucas lanata. J. Pharm. Res. 2013, 6, 368-372.

43. Meghashri, S.; Vijay Kumar, H.; Gopal, S. Antioxidant properties of a novel flavonoid from leaves of Leucas aspera. Food Chem. 2010, 122, 105-110.

44. Adams, R.P. Identification of Essential Oils Components by Gas Chromatography/Quadrupole Mass Spectroscopy; Allured: Carol Stream, IL, USA, 2001.

45. König, W.A.; Julain, D.; Hochmuth, D.H. Terpenoids and Related Constituents of Essential Oils, University of Hamburg available from MassFinder 3.5; Hochmuth Scientific Software, Hamburg, Germany, 2006.

46. Mann, C.M.; Markham, J.L. A new method for determining the minimum inhibitory concentration of essential oils. J. Appl. Microbiol. 1998, 84, 538-544.

47. Brand-Williams, W.; Cuvelier, M.E.; Berset, C. Use of a free radical method to evaluate antioxidant activity. Food Sci. Technol. 1995, 28, 25-30.

(C) 2013 by the authors; licensee MDPI, Basel, Switzerland. This article is an open access article distributed under the terms and conditions of the Creative Commons Attribution license (http://creativecommons.org/licenses/by/3.0/). 